\title{
ANALISIS PEMBENTUKAN CADANGAN KERUGIAN PENURUNAN NILAI DI BANK BTN
}

\author{
Elly Astuti ${ }^{2}$ \\ Pendidikan Akuntansi FKIP \\ Universitas PGRI Madiun \\ ellyastuti@unipma.ac.id
}

\author{
Nur Wahyuning Sulistyowati ${ }^{2}$ \\ Pendidikan Akuntansi FKIP \\ Universitas PGRI Madiun \\ nurwahyu@unipma.ac.id
}

\begin{abstract}
ABSTRAK
Penelitan bertujuan untuk mengungkapkan proses pembentukan cadangan kerugian penurunan nilai di Bank BTN. Alasan pemilihan Bank BTN sebagai fokus penelitian karena karakteristik uniknya dengan segmentasi utama pada Kredit Perumahan Rakyat (KPR) dengan jangka waktu yang relatif lama dan plafon yang cukup besar sehingga menghadapi resiko kredit yang dihadapi semakin tinggi. Penelitian ini menggunakan analisis deskriptif kualitatif sebagai metode analisisnya. Hasil penelitian menunjukkan bahwa Bank BTN telah menerapkan proses penghitungan Cadangan Kerugian Penurunan Nilai sesuai dengan standar regulasi yang berlaku sesuai dengan PAPI (2008), PSAK 55 (2015) dan Peraturan Otoritas Jasa Keuangan. Sebagai langkah manajemen risiko atas Kredit Perumahan Rakyat, Bank BTN telah melakukan sistem jual lepas dengan pengalihan risiko kepada PT. Sarana Multigriya Finansial, dengan demikian segmen utama Bank BTN yang bergerak dibidang KPR tidak berpengaruh signifikan atas penurunan nilai aset keuangan yang dimilikinya.
\end{abstract}

Kata Kunci : Cadangan Kerugian Penurunan Nilai; Risiko Kredit; PSAK 55

\begin{abstract}
Research aims to disclose the process of establishing allowance for impairment losses in Bank BTN. The reason for choosing Bank BTN as the focus of the study is because of its unique characteristics with the main segmentation in the Housing Loans (KPR) with a relatively long period of time and a large enough ceiling to face the higher credit risks faced. The method of analysis used in this research is descriptive qualitative. The results of the study show that Bank BTN has implemented the process of calculating Reserves of Impairment Losses in accordance with applicable regulatory standards in accordance with PAPI (2008), PSAK 55 (2015) and the Financial Services Authority Regulation. As a risk management measure for Housing Loan, Bank BTN has conducted a system of selling off with risk transfer to PT. Sarana Multigriya Finansial, thus the main segment of Bank BTN engaged in KPR does not significantly affect the impairment of financial assets.
\end{abstract}

Keywords : $\quad$ Provision for Impairment Losses; Credit Risk; PSAK 55

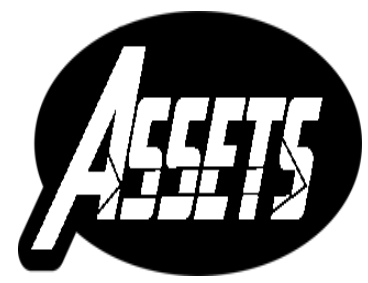

ASSETS

Jurnal Akuntansi dan Pendidikan

Vol. 7 No. 1

Hlmn. 35-44

Madiun, April 2018 p-ISSN: 2302-6251 e-ISSN: 2477-4995

Artikel masuk: 15 November 2017 Tanggal diterima: 28 April 2018 


\section{PENDAHULUAN}

Salah satu lembaga keuangan yang berfungsi untuk membentuk stabilitas perekonomian nasional adalah perusahaan perbankan. Bank memberikan jasa layanan simpanan dana dari masyarakat kemudian menyalurkannya sebagai pinjaman kepada pemilik usaha. Simulasi pinjaman dari perbankan inilah yang kemudian membantu para pelaku bisnis untuk melakukan ekspansi usahanya ataupun membantu perusahaan untuk memenuhi likuiditasnya. Kegiatan menghimpun dana yang dilakukan perusahaan perbankan juga dapat membantu perusahaan untuk memudahkan transaksi bisnis yang dijalankan serta menigkatkan efisiensi pengelolaan keuangannya. Aktivitas keuangan yang dilakukan pihak bank, akan meberikan profit berupa pendapatan bunga bagi bank.

Pendapatan bunga adalah pendapatan utama bagi operasional perusahaan perbankan. Pendapatan bunga bersih diperoleh dari selisih antara bunga atas pinjaman kredit nasabah dengan beban bunga yang harus dibayar bank atas simpanan ataupun produk perbankan lainnya yang digunakan nasabah. Semakin besar pinjaman yang diberikan kepada nasabah akan meningkatkan pendapatan bunga yang berarti meningkatkan profitabilitasnya. Namun demikian semakin besar pemberian pinjaman kepada nasabah juga meningkatkan risiko kredit macet. Untuk itu, perusahaan perbankan diwajibkan untuk membentuk cadangan kerugian penurunan nilai atas pinjaman yang diberikan kepada nasabah.

Penurunan nilai adalah suatu kondisi adanya bukti objektif terjadinya peristiwa yang merugikan sehingga mempengaruhi arus kas kontraktual di masa yang akan datang. Bank perlu membentuk cadangan kerugian penurunan nilai untuk penyisihan jika terjadi nilai kredit lebih sedikit dari nilai tercatat awalnya (PAPI, 2008: 178). Prosedur penurunan nilai ini juga telah ditetapkan dalam PSAK 55, dimana perusahaan diwajibkan untuk melakukan observasi atas instrumen keuangan yang dimilikinya. Jika terdapat bukti yang objektif, perusahaan harus mengukur dan mengakui penurunan nilai tersebut sesuai dengan klasifikasi aset keuangan yang dimilikinya.

Suhartini dan Anwar (2016) menjelaskan bahwa pembentukan beban cadangan kerugian penurunan nilai berpengaruh terhadap pendapatan dan kinerja keuangan. Beberapa penelitian terdahulu (Arthana dan Noviari, 2014; Palanggan, Tinangon dan Budiarso, 2016; Rotty, Kalangi dan Pangarepan, 2016) mengemukakan bahwa perusahaan perbankan telah mematuhi regulasi dan menerapkan pembentukan cadangan kerugian penurunan nilai pada entitasnya. Namun demikian beberapa analisis yang dilakukan hanya berdasarkan regulasi dalam PSAK. Arthana dan Noviari (2014) membandingkan proses pembentukan cadangan kerugian penurunan nilai dengan pedoman akuntansi perbankan indonesia dan peraturan menteri keuangan mengenai koreksi fiscal.

Perbedaan penelitian ini dengan penelitian sebelumnya adalah, analisis dan pembahasan didasarkan pada beberapa regulasi yang harus diterpkan pada sektor perbankan yaitu Pedoman Akuntansi Perbankan Indonesia (PAPI), Pernyataan Standar Akuntansi Keuangan (PSAk) dan peraturan Otoritas jasa Keuangan (POJK). Di samping itu, perusahaan sampel yang dianalisis adalah Bank BTN dengan karakteristik uniknya yang fokus pada segmen Kredit Perumahan Rakyat sehingga dimungkinkan akan memberikan hasil yang berbeda. Kredit Perumahan Rakyat memberikan plafon yang cukup besar kepada nasabah dengan jangka waktu yang relatif lama. Hal ini tentu akan menigkatkan resiko kredit yang mungkin akan ditanggung oleh perusahaan. Untuk itu, pembentukan cadangan kerugian penurunan 
nilai pada Bank BTN sangat berpengaruh untuk kelangsungan operasional entitas karena sangat terkait dengan kinerja keuangan dan profitabilitas perusahaan.

\section{METODE PENELITIAN}

Metode penelitian yang digunakan dalam penelitian ini adalah deskriptif dengan analissi deskriptif yaitu mengungkapkan gambaran sistematik dan faktual atas fenomena yang terjadi pada perusahaan untuk dianalisis lebih lanjut. Penelitian ini menggunakan jenis data kualitatif yang diperoleh dari dokumentasi laporan keuangan perusahaan, PSAK 50, PSAK 55, PSAK 60, PSAK 68 dan PAPI 2008. Hasil dokumentasi laporan keuangan perusahaan yang dilakukan, diperbandingkan dengan regulasi terkait baik yang bersumber dari PSAK ataupun PAPI. Proses pembandingan difokuskan pada pembentukan cadangan kerugian penurunan nilai instrumen keuangan yang dimiliki oleh Bank BTN. Hasil pembandingan kemudian dikomparasikan dengan konsep teori yang ada untuk membentuk pengembangan teori selanjutnya.

\section{HASIL PENELITIAN DAN PEMBAHASAN}

PSAK 55 memberikan regulasi bahwa penurunan nilai hanya dapat dilakukan jika terdapat bukti objektif yang mendasarinya. Apabila kerugian penurunan nilai masih berupa estimasi, tidak dapat diberlakukan pada instrument keuangan, waluapun kondisi tersebut sangat mungkin terjadi. Hal ini tentu sangat besar resikonya bagi perusahaan perbankan dengan segmen usaha utama di bidang prekreditan. Untuk itu Bank Indonesia memberikan petunjuk bahwa bank harus melakukan klasifikasi atas kreditnya sebagai bentuk penerapan prudential regulation yang tertuang dalam PAPI (2008). Bank harus sangat berhati-hati dalam mengukur, mengakui dan mengungkapkan kredit yang disalurkan kepada nasabah dengan membentuk cadangan kerugian penurunan nilai.

Bank BTN telah melakukan pembentukan cadangan kerugan penurunan nilai utamanya untuk instrumen keuangan yang dimilikinya, baik untuk instrumen ekuitas, instrumen utang, pembiayaan nasabah atapun pembiayaan syariah. Adapun beberapa penerapan beberapa regulasi dasar terkait penurunan nilai yang diterpkan di Bank BTN adalah sebagai berikut:

Tabel 1. Pembandingan Praktik Penurunan Nilai Aset Keuangan pada Bank BTN dengan Regulasi yang mendasarinya

\begin{tabular}{|c|c|c|}
\hline $\begin{array}{c}\text { Dasar Pengaturan } \\
\text { PAPI } 2008\end{array}$ & PSAK 55 Tahun 2015* & Bank BTN \\
\hline $\begin{array}{l}\text { Pada setiap tanggal neraca } \\
\text { entitas mengevaluasi } \\
\text { apakah terdapat bukti } \\
\text { obyektif bahwa aset } \\
\text { keuangan atau kelompok } \\
\text { aset keuangan mengalami } \\
\text { penurunan nilai }\end{array}$ & $\begin{array}{l}\text { Pada setiap akhir periode } \\
\text { pelaporan, } \\
\text { mengevaluasi } \\
\text { terdapat bukti objektif } \\
\text { bahwa aset keuangan atau } \\
\text { kelompok aset keuangan } \\
\text { mengalami penurunan } \\
\text { nilai (PSAK } 55 \text { Paragraf } \\
\text { 58) }\end{array}$ & $\begin{array}{l}\text { Pada setiap tanggal } \\
\text { laporan posisi keuangan, } \\
\text { Bank mengevaluasi apakah } \\
\text { terdapat bukti obyektif } \\
\text { bahwa aset keuangan yang } \\
\text { tidak dicatat pada nilai } \\
\text { wajar melalui laporan laba } \\
\text { rugi telah mengalami } \\
\text { penurunan nilai. }\end{array}$ \\
\hline $\begin{array}{l}\text { Bukti obyektif bahwa aset } \\
\text { keuangan atau kelompok } \\
\text { aset mengalami penurunan } \\
\text { nilai meliputi data yang }\end{array}$ & $\begin{array}{l}\text { Bukti obyektif bahwa aset } \\
\text { keuangan atau kelompok } \\
\text { aset keuangan mengalami } \\
\text { penurunan nilai termasuk }\end{array}$ & $\begin{array}{l}\text { Kriteria yang digunakan } \\
\text { oleh Bank untuk } \\
\text { menentukan bukti obyektif } \\
\text { dari penurunan nilai }\end{array}$ \\
\hline
\end{tabular}


ASTUTI, E. \& SULISTYOWATI, N.W. ANALISIS PEMBENTUKAN CADANGAN ...

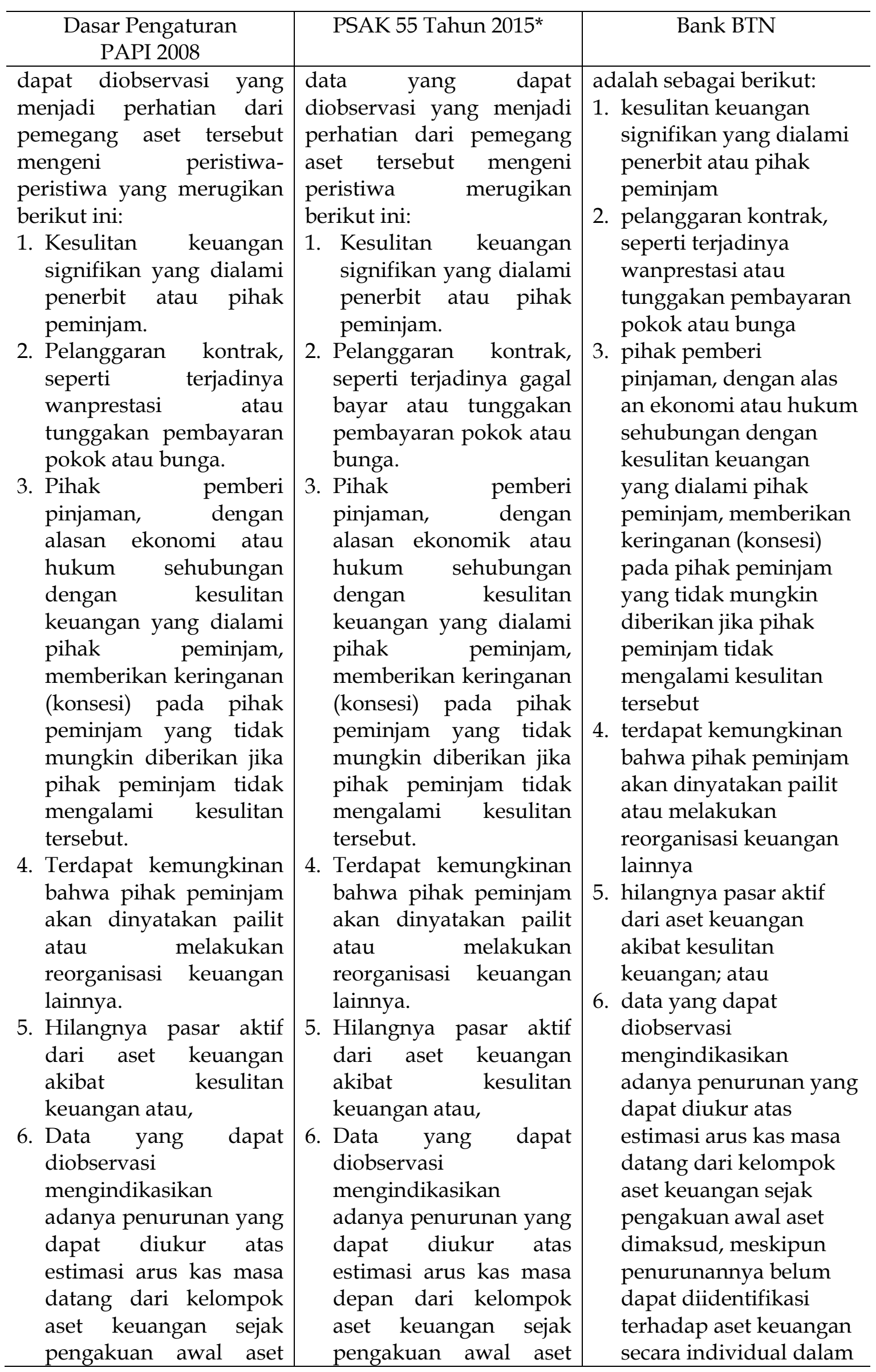




\begin{tabular}{|c|c|c|}
\hline $\begin{array}{c}\text { Dasar Pengaturan } \\
\text { PAPI } 2008\end{array}$ & PSAK 55 Tahun 2015* & Bank BTN \\
\hline 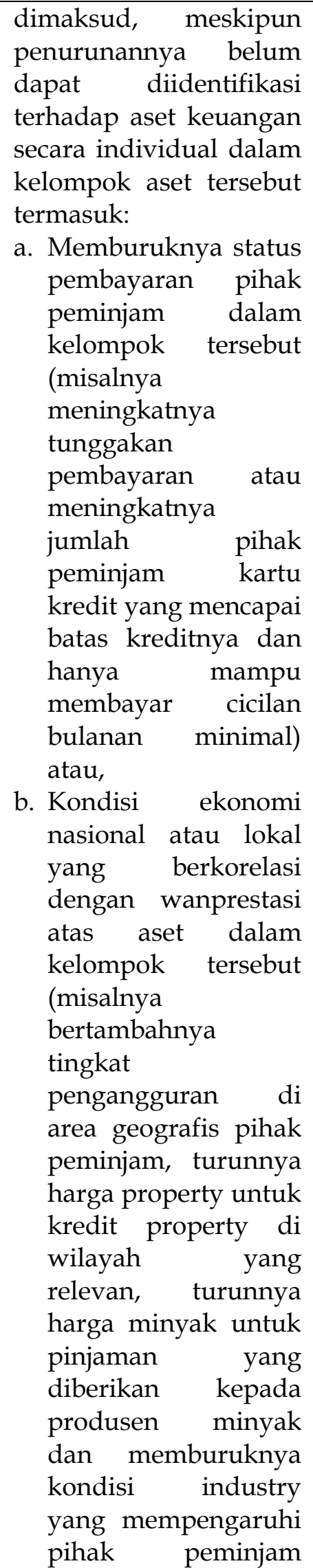 & 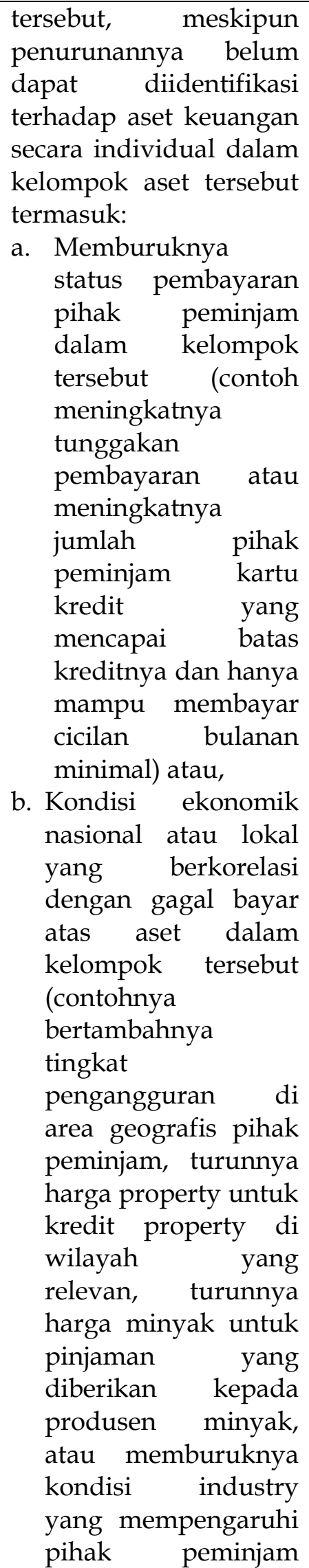 & $\begin{array}{l}\text { kelompok aset tersebut, } \\
\text { termasuk: } \\
\text { a. memburuknya } \\
\text { status pembayaran } \\
\text { pihak peminjam } \\
\text { dalam kelompok } \\
\text { tersebut; dan } \\
\text { b. kondisi ekonomi } \\
\text { nasional atau local } \\
\text { yang berkorelasi } \\
\text { dengan wanprestasi } \\
\text { atas aset dalam } \\
\text { kelompok tersebut. }\end{array}$ \\
\hline
\end{tabular}


ASTUTI, E. \& SULISTYOWATI, N.W. ANALISIS PEMBENTUKAN CADANGAN ...

\begin{tabular}{c|l|}
\hline $\begin{array}{c}\text { Dasar Pengaturan } \\
\text { PAPI 2008 }\end{array}$ & PSAK 55 Tahun 2015* \\
\hline dalam kelompok & $\begin{array}{l}\text { dalam kelompok } \\
\text { tersebut. }\end{array}$ \\
\begin{tabular}{l} 
Paragraf 59). \\
\hline
\end{tabular}
\end{tabular}

Entitas pertama kali menentukan bahwa terdapat bukti objektif mengenai penurunan nilai secara individual atas aset keuangan yang signifikan secara individual, dan untuk aset keuangan yang tidak signifikan secara individual terdapat bukti penurunan nilai secara individual atau kolektif. Jika entitas menentukan tidak terdapat bukti objektif mengenai penurunan nilai atas aset keuangan yang dinilai secara individual, terlepas aset keuangan tersebut signifikan atau tidak, maka entitas memasukkan aset tersebut ke dalam kelompok aset keuangan yang memiliki karakteristik risiko kredit yang serupa dan menilai penurunan nilai kelompok tersebut secara kolektif. Aset yang penurunan nilainya dinilai secara individual, dan untuk itu kerugian penurunan nilai diakui atau tetap diakui, tidak termasuk dalam penilaian penurunan nilai secara kolektif.
Entitas pertama kali menentukan bahwa terdapat bukti objektif mengenai penurunan nilai secara individual atas aset keuangan yang signifikan secara individual, dan secara individual atau kolektif untuk aset keuangan yang tidak signifikan secara individual. Jika entitas menentukan bahwa tidak terdapat bukti objektif mengenai penurunan nilai atas aset keuangan yang dinilai secara individual, terlepas aset keuangan tersebut signifikan atau tidak, maka entitas memasukkan aset tersebut ke dalam kelompok aset keuangan yang memiliki karakteristik risiko kredit yang serupa dan menilai penurunan nilai kelompok tersebut secara kolektif. Aset yang penurunan nilainya dinilai secara individual, dan untuk itu kerugian penurunan nilai diakui atau tetap diakui, tidak termasuk dalam penilaian penurunan nilai secara kolektif (PSAK 55 Paragraf 64).
Bank BTN

Bank menetapkan kredit yang harus dievaluasi penurunan nilainya secara individual, jika memenuhi salah satu kriteria di bawah ini:

1. Kredit yang secara individual memiliki nilai signifikan dan memiliki bukti obyektif penurunan nilai

2. Kredit yang direstrukturisasi yang secara individual memiliki nilai signifikan

Bank menetapkan kredit yang harus dievaluasi penurunan nilainya secara kolektif, jika memenuhi salah satu kriteria di bawah ini:

1. Kredit yang secara individual memiliki nilai signifikan namun tidak memiliki bukti obyektif penurunan nilai

2. Kredit yang secara individual memiliki nilai tidak signifikan

3. Kredit yang direstrukturisasi yang secara individual memiliki nilai tidak signifikan

\footnotetext{
* Penelitian ini menggunakan PSAK 2015 sebagai dasar analisis karena laporan keuangan yang digunakan masih menggunakan pedoman tersebut.

Sumber: PAPI (2008), PSAK (2015), Laporan Keuangan Bank BTN (2016).
}

Berdasarkan analisis pada Tabel 1 diketahui bahwa apa yang sudah diterapkan Bank BTN dalam praktik penurunan nilai aset keuangannya telah sesuai dengan regulasi yang tertuang dalam PAPI ataupun PSAK. Lebih jauh ditemukan bahwa dalam menentukan besarnya cadangan atas kerugian penurunan nilai atas aset keuangan, Bank BTN juga telah mematuhi peraturan Otoritas Jasa Keuangan (OJK), 
dengan jumlah cadangan kerugian penurunan nilai atas aset keuangan yang berkisar antara $1-100 \%$ bergantung pada klasifikasi risiko kredit yang diberikan.

Ketentuan OJK yang tertuang dalam POJK No. 29 Paragraf 5 Pasal 33 (2014) tentang penyelenggaraan usaha perusahaan pembiayaan, menjelaskan bahwa entitas harus memebentuk cadangan kerugian penurunan nilai atas pembiayaan yang diberikannya kepada konsumen. Adapun besaran cadangan yang wajib dialokasikan perusahaan sesuai dengan klasifikasi risiko kredit yang tertuang dalam POJK No. 16 Pasal 43 tentang Penilaian Kualitas Aset Bank Umum Syariah Dan Unit Usaha Syariah yaitu: 1) Cadangan penyisihan penghapusan aset dalam kategori lancar minimal 1\%;2) Aset Produktif yang digolongkan dalam perhatian khusus dialokasikan 5\% dari setelah dikurangi nilai agunan; 3) Aset Produktif dan Aset Non Produktif yang digolongkan kurang lancar dialokasikan 15\% setelah dikurangi nilai agunan; 4) Aset Produktif dan Aset Non Produktif yang digolongkan diragukan dialokasikan 50\% setelah dikurangi nilai agunan; atau 5) Aset Produktif dan Aset Non Produktif yang digolongkan macet dialokasikan 100\% setelah dikurangi nilai agunan.

Pada praktiknya Bank BTN telah mengklasifikasikan semua pembiayaan kepada konsumen dengan mempertimbangkan agunan yang dimilikinya. Klasifikasi tersebut digunakan sebagai dasar dalam proses penghitungan besarnya cadangan kerugian penurunan nilai aset keuangan (kredit pembiayaan) yang dimilikinya. Adapun klasifikasi yang pembiayaan kredit di Bank BTN pada tahun 2016 diilustrasikan pada Gambar 1.

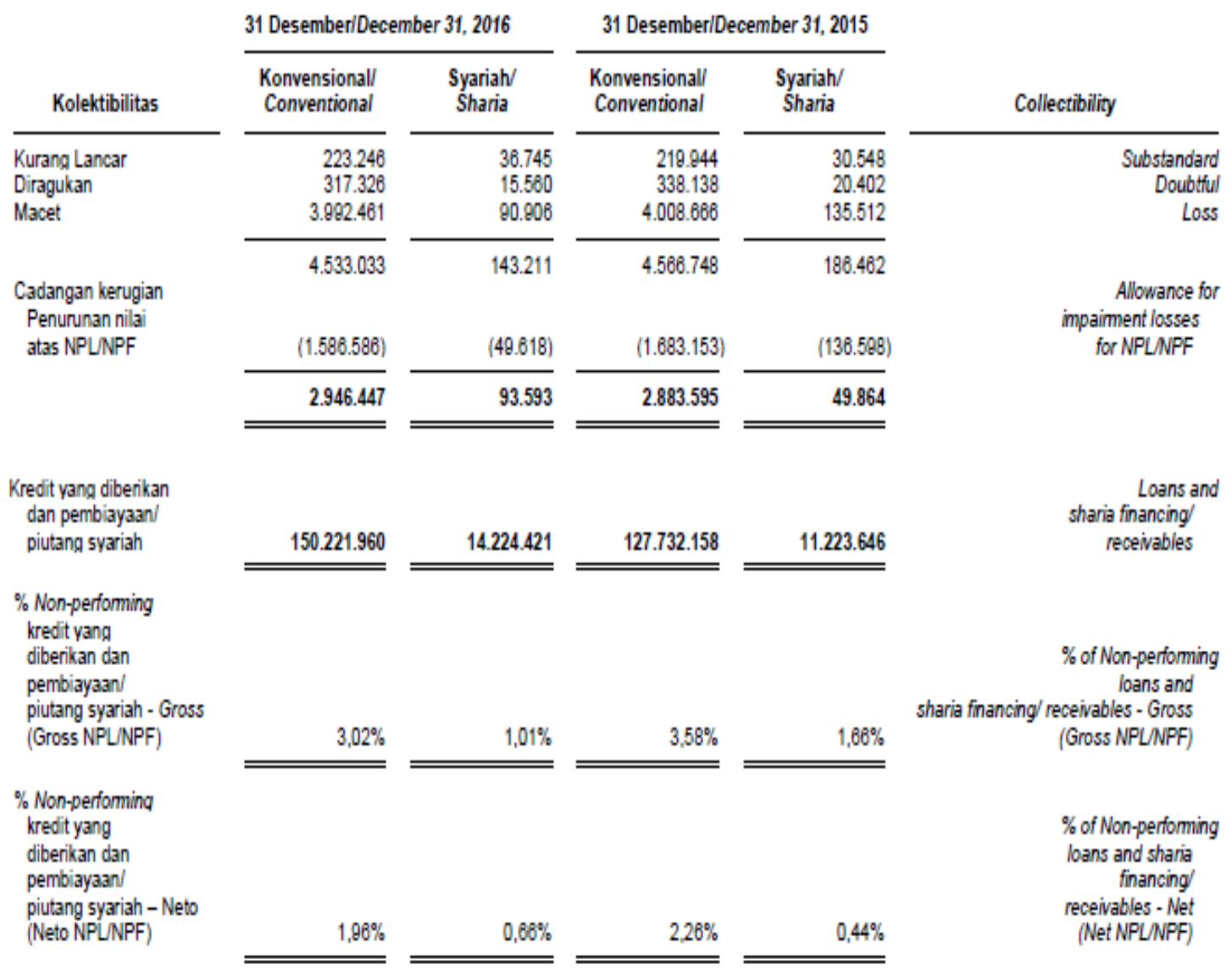

Gambar 1. Klasifikasi Pembiayaan Kredit Bank BTN

Sumber: Laporan Keuangan Bank BTN (2016) 
Regulasi pembentukan cadangan kerugian penurunan nilai sebagaimana diungkapkan dalam Tabel 1, baik aturan dalam PAPI (2008) ataupun PSAK 55 (2015) menjelaskan bahwa penurunan nilai hanya dapat diakui jika terdapat bukti objektif atas nilai aset keuangan secara individual ataupun kolektif. Untuk itu bank BTN telah menjelaskan risiko kredit pembiayaannya sesuai dengan kondisi ekonomi berbagai sector entitas mitra yang diilustrasikan pada Gambar 2.

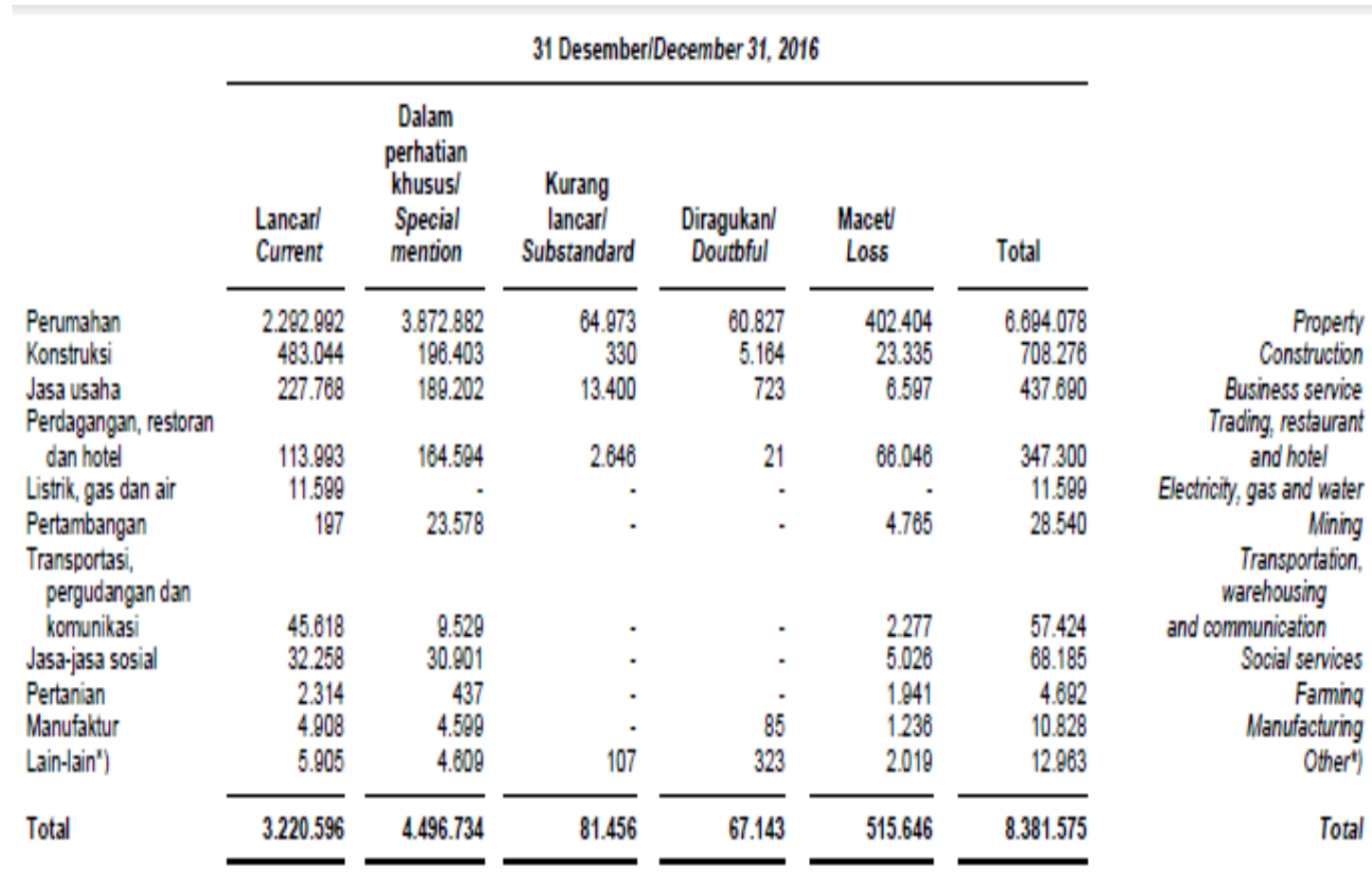

Gambar 2. Pembiayaan Bank BTN berdasarkan Kolektibilas dan Kondisi Ekonomi Sumber: Laporan Keuangan Bank BTN (2016)

Prosentase secara keseluruhan cadangan kerugian penurunan nilai yang dialokasikan oleh Bank BTN sebesar 2.116.034 dari total kredit yang diberikan senilai 164.446.381 adalah 1,287\%. Jumlah tersebut dinilai cukup untuk menutup kemungkinan terjadinya kredit macet ataupun risiko kredit lainnya karena Bank BTN menggunakan dasar pengalaman historis untuk menghitung cadangan kerugian penurunan nilainya. Pada tahun 2016, penghapusbukuan kredit bermasalah sebesar $32,15 \%$ dari cadangan kerugian penurunan nilai yang dibentuk. Hal ini membuktikan bahwa cadangan tersebut memang telah memadai.

Bank BTN yang memiliki segmen yang cukup berbeda daripada entitas pembiayaan lainnya. Fokus utama Bank BTN yang bergerak pada bidang Kredit Perumahan Rakyat (KPR) dengan periode jatuh tempo lumayan panjang akan semakin meningkatkan resiko yang dimilikinya. Untuk itu Bank BTN telah menerapkan manajemen risiko dengan system jual putus sesuai dengan aturan yang tertuang dalam PBI No.7/4/PBI/2005 tanggal 20 Januari 2005. Risiko atas penjualan kredit perumahan telah dialihkan kepada PT. Sarana Multi Griya dengan demikian segmen usaha utama Bank BTN yang fokus pada KPR tidak mempengaruhi proses pembentukan cadangan kerugian penurunan nilai secara signifikan. 


\section{SIMPULAN}

Berdasarkan analisis yang telah dilakukan terhadap proses pembentukan cadangan kerugian penurunan nilai di Bank BTN ditemukan bahwa pada praktiknya bank telah mematuhi semua regulasi yang berlaku diantaranya PAPI, PSAK dan Peraturan OJK. Bank BTN telah melakukan klasifikasi kredit pembiayaanya secara komprehensif merliputi risiko kolektabilitas, kondisi ekonomi, kondisi geografis dan beberapa pertimbangan lainnya yang mempengaruhi risiko gagal bayar konsumen. Bank BTN menggunakan dasar pengalaman historis (historical experience) dan prosentase penyisiha penghapusan aset yang telah ditetapkan OJK dalam menetapkan besarnya cadangan kerugian penurunan nilai.

Kelemahan dalam penelitian ini adalah perusahaan yang dianalisis hanya satu perusahaan perbankan. Kondisi entitas bank lainnya mungkin akan berbeda karena Bank BTN mempunyai segmen khusus bidang KPR. Di samping itu regulasi yang digunakan sebagai dasar pembentukan cadangan kerugian penurunan nilai pada penelitian ini mengacu pada PSAK 55, PAPI 2008 dan POJK. PSAK 55 (2015) sampai dengan saat ini, masih mengacu pada IAS 39. Sedangkan PAPI 2008 juga mengacu pada aturan dalam PSAK 55. PSAK 55 (2015) dalam revisi yang direncanakan akan mengacu pada IFRS karena proses pembentukan cadangan kerugan penurunan nilai dianggap terlalu sedikit dan terlalu telat untuk perkembangan bisnis global yang sangat pesat.

Penelitian sejenis di masa yang akan datang dimungkinkan akan sangat berbeda karena regulasi yang mendasari (penyesuaian PSAK 55 kepada IFRS 9) memberikan dampak yang sangat berbeda secara signifikan. Pengembangan penelitian pada sektor entitas pembiayaan lainnya dengan segmentasi usaha yang berbeda dimungkinkan akan mengungkapkan fenomena yang berbeda.

\section{DAFTAR PUSTAKA}

Arthana, I. B, dan Noviari, N. 2014. Analisis Perhitungan Cadangan Kerugian Penurunan Nila PT. Bank Sinar Harapan Bali Tahun 2011. E-journal akuntansi universitas udayana, vol. 8 (2): 102-117.

Bank Indonesia. 2008. Pedoman Akuntansi Perbankan di Indonesia. Diakses pada 08 Januari 2018, www.bi.go.id/id/perbankan/pedoman-akuntansi

Bank Indonesia. 2012. Peraturan Bank Indonesia tentang Penilaian Kualitas Aset Bank Umum. Jakarta: Bank Indonesia

Ikatan Akuntan Indonesia. 2015. Standar Akuntansi Keuangan. Jakarta: Ikatan Akuntan Indonesia

Otoritas Jasa Keuangan. 2014. Peraturan Otoritas Jasa Keuangan tentang Penyelenggaran Usaha Perusahaan Pembiayaan. Jakarta: Otoritas Jasa Keuangan.

Otoritas Jasa Keuangan. 2014. Peraturan Otoritas Jasa Keuangan tentang Penilaian Kualitas Aset Bank Umum Syariah dan Unit Usaha Syariah. Jakarta: Otoritas Jasa Keuangan.

Otoritas Jasa Keuangan. 2017. Peraturan Otoritas Jasa Keuangan tentang Penetapan Status dan Tindak Lanjut Pengawasan Bank Umum. Jakarta: Otoritas Jasa Keuangan.

Palanggan, D. D., Tinangon, J. J., dan Budiarso, N. S. 2016. Analisis Penyajian, Pengakuan, dan Pengukuran serta Pengungkapan Kredit Bermasalah (Non Performing Loan) Sesuai PSAK Nomor 50, 55 dan 60 Pada PT. Bank Sulutgo (Persero) Tbk. Vol 4 (4): 852-860. 
Rotty, R., Kalangi, L., dan Pangerapan, S. 2016. Analisis Penerpan Pengungkapan Informas Aset Keuangan Menurut PSAk 60 (Studi Kasus Pada PT. Bank Tabungan Pensiun Nasional. Tbk). Jurnal EMBA, Vol 4 (1):242-250.

Suhartini, M dan Anwar, S. 2016. Penerapan Cadangan Kerugian Penurunan Nilai, Pendapatan Murabahah dan Kinerja Keuangan Pada Bank Umum Syariah Tahun 2014. Jurnal Liquidity, V01 5 (2): 119-126. 